\title{
COMMENTARY
}

\section{Does digit ratio (2D:4D) predict penile length?}

\author{
Denise Brooks McQuade
}

Asian Journal of Andrology (2011) 13,667-668; doi:10.1038/aja.2011.81; published online 4 July 2011

Now advertized in at least one locale as the 'sexy ratio' with the caption, 'Your hands give away your hotness' (http://io9.com/ \#!5794008; accessed 3 May 2011), an online summary of a recent study linking facial attractiveness to the ratio of the index and ring fingers ${ }^{1}$ indicates that digit ratio $(2 \mathrm{D}: 4 \mathrm{D})$ research has reached mainstream culture. Digit ratio, most commonly the ratio of the index to ring fingers in humans, is sexually dimorphic (males have lower values than females) with greater differences on their right hand. ${ }^{2,3}$ Ratios are determined early in development and remain relatively stable thereafter. ${ }^{4}$ Perhaps the popular appeal is the relative simplicity of the measure, and the fact that researchers interested in any number of behavioral or physiological traits correlated with hormone activity have adopted digit ratio as a convenient biomarker for prenatal androgen exposure. ${ }^{5}$ Over the past decade, the correlation of digit ratio with sexual behavior and other aspects of reproductive biology has been well documented ${ }^{6-9}$ and there is a growing list of traits with links to digit ratio, although the associations are less well established.

Still, the use of digit ratio as an indicator of androgen activity is not without criticism. An earlier report associating digit ratio and number of CAG repeats in the androgen receptor ${ }^{10}$ recently failed to replicate. ${ }^{11}$ Similarly, much attention has been placed on the role of HOX $A$ and $D$ genes, since these are active early in the development of both limbs and gonads and could account for the relationship between hormone activity and digit ratio. However, it was neither the HOX nor the androgen receptor genes but an entirely different gene (LIN28B) that was related to digit ratio in a recent study. ${ }^{12}$ These criticisms, however, reflect increased focus on potential mechanisms (including a discussion of genetic

Department of Biology, Skidmore College, Saratoga Springs, NY 12866, USA

Correspondence: Dr DB McQuade (dmcquade@

skidmore.edu) contributions) underlying the development of the digit ratio trait, which remain to be elucidated.

Amidst a flurry of 2D:4D publications, mostly indicative of positive findings, ${ }^{13}$ these criticisms were brought to light in a recent Asian Journal of Andrology report. ${ }^{14}$ The authors, Choi et al., provide convincing support for a relationship between digit ratio and penile length. The researchers measured right hand digits directly with calipers, averaging repeated measures to calculate digit ratio. Flaccid and stretched penile lengths were measured in anesthetized patients with a rigid ruler, by a second researcher blind to the digit measurements. Digit ratio was strongly (negatively) correlated with stretched penile length $(P=0.024)$. Choi et al. ${ }^{14}$ concluded that higher prenatal androgen exposure is responsible for both the lower digit ratio and the longer penile length.

In their discussion, the authors make their case for the predictive ability of digit ratio on adult stretched penile length. They counter criticisms that the longer penile lengths reflect testosterone's analgesic properties, because patients were anesthetized. Choi et al. also argue that the homogeneous subject pool (Korean) reduced potential confounding variability since race and ethnicity are known to influence digit ratio., ${ }^{4,9}$ The researchers also suggest that the subject pool was absent of patients whose medical conditions were known to be correlated with digit ratio. However, given the increasingly long list of physical, medical and behavioral conditions related to digit ratio, this may have been an impossible task. Though the authors report that Asian men have slightly shorter penises compared to other groups, and that the ethnic Han have the highest reported male digit ratios, they were not able to address the extent to which their digit ratio-penile length correlation may be specific to the particular ethnic composition of their study sample.
Of potential interest to the readers of the Asian Journal of Andrology is a 2011 report linking risk of prostate cancer to digit ratio. ${ }^{15}$ Unlike the precise measurements of digits with high repeatability obtained by Choi et $a l .{ }^{14}$, the researchers in the United Kingdom adopted a questionnaire format in order to secure the largest possible sample size (over 1500 prostate cancer patients and over 3000 controls). Participants matched hand patterns with one of three drawings supplied by the researchers: index finger shorter than ring finger (low digit ratio); index finger equal to ring finger; or index finger longer than ring finger (high digit ratio). Participants with index finger longer than ring finger were significantly less likely to have prostate cancer and the authors concluded that high digit ratio may confer a protective effect against the disease.

Thus 'hotness' aside, the value of digit ratio research for the biomedical scientist or clinician may come from the predictive abilities and risk-assessment qualities of the measurement for clinical conditions that are a function of individual histories for developmental androgenic effects.

1 Ferdenzi C, Lemaitre JF, Leongomez JD, Roberts SC Digit ratio (2D:4D) predicts facial, but not voice or body odour, attractiveness in men. Proc Biol Sci; e-pub ahead of print 20 April 2011; doi:10.1098/ rspb.2011.0544.

2 Manning JT, Scutt D, Wilson J, Lewis-Jones DI. The ratio of 2 nd to 4 th digit length: a predictor of sperm numbers and concentrations of testosterone, luteinizing hormone and oestrogen. Hum Reprod 1998; 13: 3000-4.

3 McFadden D, Shubel E. Relative lengths of fingers and toes in human males and females. Horm Behav 2002; 42: 492-500.

4 Manning JT, Stewart A, Bundred PE, Trivers RL. Sex and ethnic differences in 2 nd to 4 th digit ratio of children. Early Hum Dev 2004; 80: 161-8.

5 Mclntyre $\mathrm{MH}$. The use of digit ratios as markers for perinatal androgen action. Reprod Biol Endocrinol 2006; 4: 10 .

6 Williams TJ, Pepitone ME, Christensen SE, Cooke BM Huberman $A D$ et al. Finger-length ratios and sexual orientation. Nature 2000; 404: 455-6. 
7 Fink B, Neave N, Manning JT. Second to fourth digit ratio, body mass index, waist-to-hip ratio, and waist-to-chest ratio: their relationships in heterosexual men and women. Ann Hum Biol 2003; 30: 728-38.

8 Hall LS, Love CT. Finger-length ratios in female monozygotic twins discordant for sexual orientation. Arch Sex Behav 2003; 32: 23-8.

9 Manning JT, Churchill AJ, Peters M. The effects of sex, ethnicity, and sexual orientation on selfmeasured digit ratio (2D:4D). Arch Sex Behav 2007; 36: 223-33.
10 Manning JT, Bundred PE, Flanagan BF. The ratio of 2nd to 4th digit length: a proxy for transactivation activity of the androgen receptor gene? Med Hypotheses 2002; 59: 334-6.

11 Hurd PL, Vaillancourt KL, Dinsdale NL. Aggression, digit ratio and variation in androgen receptor and monoamine oxidase A genes in men. Behav Genet; e-pub ahead of print 22 October 2010; doi:10. 1007/s10519-010-9404-7.

12 Medland SE, Zayats T, Glaser B, Nyholt DR, Gordon $\mathrm{SD}$ et al. A variant in LIN28B is associated with $2 \mathrm{D}: 4 \mathrm{D}$ finger-length ratio, a putative retrospective biomarker of prenatal testosterone exposure. Am J Hum Genet 2010; 86: 519-25.

13 Voracek M, Loibl LM. Scientometric analysis and bibliography of digit ratio (2D:4D) research, 19982008. Psychol Rep 2009; 104: 922-56.

14 Choi IH, Kim KH, Jung H, Yoon SJ, Kim SW et al. Second to fourth digit ratio: a predictor of adult penile length. Asian J Androl 2011. e-pub ahead of print 4 July, 2011; doi:10.1038/aja.2011.75.

15 Rahman AA, Lophatananon A, Stewart-Brown S, Harriss $\mathrm{D}$, Anderson $\mathrm{J}$ et al. Hand pattern indicates prostate cancer risk. Br J Cancer 2011; 104: 175-7. 